\title{
INTRA ASEAN-5 CAPITAL FLOWS: DO THEY REPRESENT NEOCLASSICAL BELIEF OR LUCAS PARADOX?
}

\author{
Nurul Qolbi \\ Akhmad Syakir Kurnia ${ }^{2}$
}

\begin{abstract}
In the neoclassical belief, capital flows downhill from rich to poor countries as a consequence of capital endowment variation. In contrast to the neoclassical belief, Lucas found evidence that capital tends to flow uphill. This paper investigates the intra ASEAN-5 capital flows. Using panel estimation, we found that marginal product of capital, human capital, total factor productivity growth, and the quality of institutions appear as determinants for the capital flow from Indonesia, Malaysia, Philippines, and Thailand to Singapore as a host country. On the contrary, the capital flow from Singapore to other ASEAN countries as host countries is encouraged only by the quality of institutions, human capital as well as per capita GDP. The result shows that Lucas variables emerge as determinants for the uphill and downhill capital flow in ASEAN-5. In the meantime, marginal product of capital that represents neoclassical variable appears as the determinant for uphill capital flow from other ASEAN countries to Singapore. This gives significant insight that Lucas variables emerge as companion to the neoclassical variables in explaining intra ASEAN capital flow.
\end{abstract}

Keywords: capital flow, neoclassical belief, lucas paradox, panel data model

\section{JEL Classification: F21, 016}

1 Department of Economics and Development Studies, Faculty of Economics and Business, Diponegoro University (uul.qolbi@gmail. com).

2 Department of Economics and Development Studies, Faculty of Economics and Business and Center of Development Research, Diponegoro University (akhmadkurnia@undip.ac.id) 


\section{PENDAHULUAN}

Lalu lintas modal antar negara yang masif merupakan peluang masuknya investasi dan modal asing untuk mendorong pertumbuhan ekonomi. Kelancaran aliran modal memungkinkan peningkatan akumulasi modal di negara penerima (host country) dan membantu diversifikasi risiko. Hal ini dapat pula berimplikasi pada efisiensi alokasi modal hingga akhirnya mendukung pertumbuhan ekonomi (Okada, 2013).

Penghapusan hambatan atas lalu lintas modal juga akan menarik investor untuk berinvestasi di suatu negara. Hal tersebut selanjutnya akan membantu posisi neraca pembayaran, mengurangi biaya pinjaman, dan bermuara pada pertumbuhan ekonomi (Djaafara, dkk, 2012). Sementara secara tidak langsung, aliran modal masuk berkontribusi dalam mempromosikan pertumbuhan produktivitas melalui transfer teknologi (Okada, 2013). Selain itu, mobilitas modal internasional memfasilitasi penyaluran sumber daya keuangan global untuk kegiatan-kegiatan produksi (Alfaro, Kalemli-Ozcan, dan Volosovych, 2007).

Teori neoklasik mengungkapkan, modal mengalir "downhill" dari negara kaya (capital abundant) ke negara miskin (capital scarce). Ketika semua negara dapat mengakses teknologi yang sama dan menghasilkan barang sejenis, sementara perbedaan pendapatan per kapita menggambarkan perbedaan tingkat pengembalian modal, maka investasi baru akan dilakukan di negara-negara miskin. Di sisi lain, secara eksplisit model Heckscher-Ohlin memprediksi modal mengalir dari negara-negara dengan suku bunga rendah ke negara-negara dengan tingkat suku bunga tinggi (Pogoda, 2012).

Akan tetapi, Robert E. Lucas, Jr (1990) dalam artikel berjudul "Why doesn't capital flow from rich to poor countries?" mempertanyakan validitas asumsi yang digunakan pada model neoklasik. Lucas menemukan bukti empiris bahwa modal mengalir "uphill" dari negara miskin ke negara kaya. Fenomena ini kemudian dikenal dengan istilah "Paradoks Lucas." Menurutnya, apabila model neoklasik terbukti serta pasar modal internasional menjadi bebas dan sempurna, negara-negara akan menghadapi perbedaan tingkat pengembalian modal dan investasi.

Penjelasan teoritis mengenai Paradoks Lucas dibagi menjadi dua (Alfaro, 2008). Pertama, mencakup perbedaan fundamental yang memengaruhi struktur produksi dalam perekonomian, seperti perbedaan teknologi, faktor-faktor yang dihilangkan dalam fungsi produksi, kebijakan pemerintah, serta struktur kelembagaan. Alfaro (2008) dalam penelitiannya menyimpulkan, bahwa meningkatnya aliran modal internasional sebagai dampak dari keterbukaan keuangan sejalan dengan peningkatan kualitas kelembagaan.

Kedua, ketidaksempurnaan pasar modal karena informasi asimetris dan sovereign risk. Studi empiris Herrmann dan Kleinert (2014) pada negara-negara yang tergabung dalam European Monetary Union (EMU) menunjukkan, ketidaksempurnaan pasar akan menghambat efisiensi alokasi modal. Akibatnya, aliran modal ke negara-negara miskin dan dalam perspektif 
dinamis; Allocation Puzzle ${ }^{3}$ ke negara yang perekonomiannya tumbuh dengan cepat (fastgrowing economies) lebih rendah dari perkiraan model neoklasik.

Negara-negara di kawasan Asia Tenggara (ASEAN) kini telah mencapai perkembangan tahapan liberalisasi lalu lintas modal Foreign Direct Invstment (FDI), khususnya inward investment dan likuidasi. Akan tetapi untuk outward investment terdapat pembatasan jumlah maksimum di Malaysia, Philipina, dan Thailand, namun secara bertahap akan mulai dilakukan penghapusan hambatan pada $2010^{4}$.

\begin{tabular}{|c|c|c|c|c|c|c|c|c|c|c|c|}
\hline \multicolumn{12}{|c|}{$\begin{array}{l}\text { Tabel } 1 \\
\text { Aliran FDI Intra-ASEAN Tahun } 2011 \text { (dalam juta USD) }\end{array}$} \\
\hline SOURCE & $\begin{array}{c}\text { Brunei } \\
\text { Darussalam }\end{array}$ & Cambodia & Indonesia & $\begin{array}{l}\text { Lao } \\
\text { PDR }\end{array}$ & Malaysia & Myanmar & Philippines & Singapore & Thailand & Vietnam & TOTAL \\
\hline Brunei Darussalam & - & - & 0.05 & - & 79.01 & - & 0.00 & 30.10 & 0.99 & 40.67 & 150.83 \\
\hline Cambodia & - & - & - & - & 31.67 & - & - & 0.00 & 0.78 & 0.62 & 33.07 \\
\hline Indonesia & 0.33 & 0.00 & - & - & 41.33 & 79.80 & $(0.64)$ & 1985.20 & 13.02 & 14.84 & 2133.87 \\
\hline Lao PDR & - & - & - & - & $(0.06)$ & - & - & - & 0.48 & 0.38 & 0.80 \\
\hline Malaysia & 33.70 & 71.33 & (292.79) & 0.30 & - & 1.10 & 32.62 & 1863.20 & $(138.55)$ & 232.00 & 1802.91 \\
\hline Myanmar & - & - & - & - & $(2.17)$ & - & - & 127.20 & $(4.41)$ & - & 120.63 \\
\hline Philippines & 0.11 & - & 10.04 & - & 5.99 & - & - & $(529.90)$ & 6.33 & 1.28 & $(506.15)$ \\
\hline Singapore & 33.33 & 40.32 & 8514.13 & 2.04 & 2057.62 & 0.20 & (77.14) & - & 69.45 & 1129.81 & 11769.76 \\
\hline Thailand & - & 20.48 & 101.52 & 23.70 & 370.97 & 3.50 & $(28.76)$ & $(1194.90)$ & - & 97.73 & $(605.76)$ \\
\hline Viet Nam & - & 91.69 & 1.51 & 48.97 & 79.96 & - & $(0.18)$ & 80.10 & 11.24 & - & 303.29 \\
\hline ASEAN & 67.47 & 223.82 & 8334.45 & 75.00 & 2664.32 & 84.60 & $(74.10)$ & 2386.20 & $(50.66)$ & 1517.34 & 15228.44 \\
\hline
\end{tabular}

Sumber: ASEAN Secretariat - ASEAN FDI Database, 31 Desember 2014

Pada tahun 2011, FDI yang masuk ke ASEAN secara keseluruhan sebesar 97.538,12 juta USD dengan rincian, 15.228,44 juta USD dari intra-ASEAN dan 83.564,36 juta USD dari luar ASEAN. Aliran FDI intra-ASEAN pada tahun 2011 dapat dilihat pada Tabel 1. Aliran FDI intraASEAN sebagian besar terkonsentrasi di ASEAN-5 dan hanya sedikit yang bergerak ke negara ASEAN lainnya (Brunei Darussalam, Kamboja, Laos, Myanmar, dan Vietnam, BCLMV). Hal ini seolah menegasikan bahwa arus modal di ASEAN paling besar bergerak menuju ASEAN 5. Dari total FDI yang masuk ke ASEAN 5 pada tahun tersebut, Indonesia menjadi negara penerima FDI intra-ASEAN terbesar, yakni 8.334,45 juta USD, dengan Singapura sebagai negara asal (source country) sebesar 8.514,13 juta USD. Dengan demikian, apabila dilihat jumlah FDI yang berasal dari negara-negara satu kawasan, paling tinggi ke Indonesia negara dengan pendapatan per

3 Gourinchas dan Jeanne (2007) membuktikan bahwa modal yang mengalir ke negara berkembang (emerging markets) tidak hanya sedikit berdasarkan ukuran, tetapi juga dialokasikan ke nagara-negara dengan pertumbuhan ekonomi kurang dari negara berkembang lainnya.

$414^{\text {th }}$ Meeting of the ASEAN Working Committee on Capital Account Liberalization, Kuala Lumpur, Juli 2009. Lihat Djafaara, dkk, (2012). 
kapita rendah hal ini sejalan dengan model neoklasik. Akan tetapi hal tersebut tidak terjadi di Philipina, negara yang juga memiliki pendapatan per kapita rendah.

Pergerakan modal yang sejalan dengan neoklasik tersebut dapat diterima argumentasinya dengan melihat faktor-faktor yang menjelaskan. Namun demikian, bagaimana sesungguhnya pergerakan modal yang terjadi di ASEAN 5 apabila diasumsikan negara di kawasan tersebut menutup diri dari aliran modal yang berasal dari negara-negara non-ASEAN? Apakah Paradoks Lucas terjadi di kawasan ini? Pertanyaan-pertanyaan penting inilah yang melandasi penelitian yang dituangkan dalam paper ini.

Bagian selanjutnya dari paper ini menguraikan teori dan studi literatur yang terkait. Bagian ketiga menyajikan data dan teknik pengolahan data yang digunakan. Bagian keempat mengulas hasil estimasi dan analisisnya, sementara kesimpulan disajikan pada bagian kelima dan menjadi penutup dari paper ini.

\section{TEORI}

Penelitian mengenai aliran modal internasional antara lain dilakukan oleh Lucas (1990). Menurut penghitungan Lucas, pada tahun 1988 MPK India 58 kali dari Amerika Serikat. Namun setelah mempertimbangkan perbedaan modal manusia (stocks of human capital), hasilnya memperkirakan produktivitas setiap tenaga kerja di negara kaya (Amerika Serikat) setara dengan lima orang di negara miskin (India). Apabila perbedaan modal manusia antar negara dipertimbangkan, maka aliran modal ke negara miskin lebih sedikit daripada yang diprediksi oleh model neoklasik. Sebaliknya, pembentukan modal manusia di negara kaya mendorong aliran modal ke negara yang memiliki kelimpahan modal.

Alfaro, Kalemli-ozcan, dan Volosovych (2007) (AKV) melakukan penelitian mengenai aliran modal antar negara di dunia dan volatilitas faktor penentunya sepanjang tahun 19702000. Secara teoritis, kualitas kelembagaan merupakan faktor penentu aliran modal yang paling penting. Sedangkan, secara empiris, kualitas kelembagaan terkait erat dengan modal manusia maupun sovereign risk. Kurangnya aliran modal dari negara kaya ke negara miskin kemudian mendorong AKV melakukan studi lanjutan pada tahun 2008. Studi ini dimaksudkan untuk menguji fenomena Paradoks Lucas. Hasil penelitian AKV (2008) menyimpulkan, kualitas kelembagaan merupakan variabel kausal dalam penjelasan Paradoks Lucas. Terdapat perbedaan kualitas kelembagaan di antara negara kaya dan miskin. Kebijakan memperkuat perlindungan hak milik, mengurangi korupsi, meningkatkan stabilitas pemerintah, kualitas birokrasi, serta hukum dan ketertiban harus dilakukan pemerintah negara miskin dalam upaya meningkatkan aliran masuk modal. Selain itu, investasi asing yang masuk karena adanya peningkatan kualitas kelembagaan akan berpengaruh pada pembangunan jangka panjang.

Okada (2013) juga melakukan penelitian mengenai Paradoks Lucas dengan fokus pada dua faktor yang menjelaskan aliran modal. Dampak globalisasi sektor keuangan terhadap 
aliran modal internasional diduga Okada tergantung pada kualitas kelembagaan suatu negara. Sementara keterbukaan keuangan dan kualitas kelembagaan diduga berkorelasi positif. Hasilnya menunjukkan, bahwa keterbukaan sektor keuangan dan kualitas kelembagaan tidak berdampak signifikan terhadap arus modal internasional secara individu. Akan tetapi interaksi di antara keduanya berdampak signifikan. Selain itu, faktor institusi, kualitas birokrasi, hukum, dan ketertiban memiliki peran penting dalam FDI. Keterbukaan keuangan dan peningkatan kualitas kelembagaan menyebabkan arus masuk modal internasional yang dianggap sebagai sumber penting dalam pembangunan ekonomi.

Studi empiris mengenai Paradoks Lucas di negara-negara dalam satu kawasan dilakukan oleh Herrmann dan Kleinert (2014). Penelitian ini berfokus pada negara-negara yang tergabung dalam European Monetary Union (EMU) untuk melihat apakah terdapat perbedaan aliran modal di kawasan tersebut baik berdasarkan hipotesis Paradoks Lucas maupun Allocation Puzzle. Hasilnya, tidak ditemukan bukti empiris yang mendukung Paradoks Lucas untuk arus modal internasional. Setelah mengevaluasi fenomena Paradoks Lucas di pasar negara berkembang, ditemukan bukti empiris bahwa Paradoks Lucas berlaku di negara-negara yang sedang mengejar ketertinggalan dan di antaranya, modal bersih mengalir ke negara kaya. Sementara itu, setelah menyelidiki perilaku arus bruto, hasilnya menunjukkan bahwa aliran modal internasional (bruto) sesuai dengan Paradoks Lucas. Di lain sisi, ketidaksempurnaan pasar akan menghambat efisiensi alokasi modal. Akibatnya, aliran modal ke negara-negara miskin dan dalam perspektif dinamis; Allocation Puzzle ke negara yang berkembang dengan cepat (fast-growing economies) lebih rendah dari perkiraan model neoklasik.

Untuk memperoleh gambaran yang lebih lengkap tentang bagaimana model empiris yang digunakan dalam berbagai penelitian di atas, maka pada bagian di bawah ini disajikan teori dasar pergerakan modal dan faktor-faktor yang mendorongnya.

\subsection{Teori Investasi Neoklasik}

Investasi merupakan salah satu variabel pengeluaran agregat dalam komponen pendapatan nasional (Gross Domestic Product/ GDP) meski jumlahnya relatif lebih sedikit dibanding pengeluaran konsumsi (Mankiw, 2013). Investasi dibedakan menjadi tiga, yaitu investasi bisnis tetap (mesin dan peralatan), investadi residensial (konstruksi), dan investasi persediaan yang semuanya dibeli oleh sektor swasta. Model investasi bisnis tetap teori investasi neoklasik mengkaji biaya dan manfaat untuk memiliki barang modal. Teori ini mengasumsikan terdapat dua jenis perusahaan. Pertama, perusahaan produksi yang menghasilkan barang dan jasa menggunakan modal yang disewa. Kedua, perusahaan penyewaan (disebut pula pemilik modal) yang membeli modal dan menyewakannya kepada perusahaan produksi.

Perusahaan menyewakan modal pada tingkat sewa $(R)$ dan menjual output pada tingkat harga (P). Sementara itu, perusahaan produksi menanggung biaya riil sebesar (R/P) untuk setiap 
satu unit modal. Dengan demikian, tambahan manfaat riil yang diperoleh untuk setiap satu unit modal adalah marginal product of capital (MPK). MPK merupakan tingkat pengembalian dari penanaman atau penyewaan modal. Apabila perusahaan penyewaan ingin memaksimalkan keuntungan, maka modal disewakan hingga MPK sama dengan harga sewa riil.

Untuk menjelaskan harga sewa keseimbangan dan variabel-variabel yang mempengaruhinya digunakan fungsi produksi Cobb-Douglas berikut:

$$
Y=A K^{\alpha} L^{1-\alpha}
$$

dengan ( $\mathrm{Y}$ ) adalah output, $(\mathrm{K})$ modal, $(\mathrm{L})$ tenaga kerja, $(\mathrm{A})$ teknologi, dan a merupakan parameter antara nol dan satu yang mengukur bagian modal atas output. Sementara itu, MPK (r) untuk fungsi produksi Cobb-Douglass adalah:

$$
r=\alpha A(L / K)^{1-\alpha}
$$

Karena dalam kondisi keseimbangan harga sewa riil sama dengan MPK, maka:

$$
R / P=\alpha A(L / K)^{1-\alpha}
$$

Persamaan (3) menunjukkan semakin kecil persediaan modal, semakin banyak tenaga kerja yang dipekerjakan, dan semakin baik teknologi yang digunakan, semakin tinggi harga sewa riil dari modal.

Di sisi lain, penerimaan yang diperoleh perusahaan penyewaan modal merupakan manfaat dari kepemilikan modal. Perusahaan penyewaan modal menerima harga sewa riil dari modal (R/P) untuk setiap modal yang dimiliki dan disewakan. Meski demikian, perusahaan penyewaan juga menanggung biaya atas kepemilikan modalnya, yaitu bunga pinjaman (), biaya dari kerugian maupun keuntungan perusahaan penyewaan (), dan depresiasi (), sehingga:

$$
\begin{aligned}
& \boldsymbol{R}_{K}=i P_{K}-\Delta P_{K}+\delta P_{K} \\
& R_{K}=P_{K}\left(i-\Delta P_{K} / P_{K}+\delta\right)
\end{aligned}
$$

Apabila diasumsikan harga barang modal meningkat seiring dengan harga barang-barang lain, dimana $\Delta P_{K} / P_{K}$ sama dengan tingkat inflasi keseluruhan $\tau$, maka biaya modal bergantung pada harga modal, tingkat bunga riil, dan tingkat depresiasi, sehingga:

$$
\boldsymbol{R}_{\boldsymbol{K}}=\boldsymbol{P}_{\boldsymbol{K}}(\boldsymbol{i}+\boldsymbol{\delta})
$$


Sementara itu, biaya modal riil ${ }^{5}$ adalah:

$$
\boldsymbol{R}_{K_{\text {riil }}}=\left(\boldsymbol{P}_{K} / \boldsymbol{P}\right)(\boldsymbol{i}+\boldsymbol{\delta})
$$

Hal ini berarti, bahwa biaya modal riil tergantung harga relatif dari barang modal, tingkat bunga, dan tingkat depresiasi.

Perusahaan penyewaan akan menghasilkan penerimaan riil (R/P) dan menanggung biaya riil untuk setiap unit modal yang disewakan. Dengan demikian, keuntungan riil per unit modal ialah:

$$
\boldsymbol{\pi}=(\boldsymbol{R} / \boldsymbol{P})-\left(\boldsymbol{P}_{\boldsymbol{K}} / \boldsymbol{P}\right)(\boldsymbol{i}+\boldsymbol{\delta})
$$

Karena harga sewa riil dalam kondisi keseimbangan MPK, maka keuntungan per unit modal yang diperoleh ialah:

$$
\boldsymbol{\pi}=\boldsymbol{r}-\left(\boldsymbol{P}_{\boldsymbol{K}} / \boldsymbol{P}\right)(\boldsymbol{i}+\boldsymbol{\delta})
$$

Dari Persamaan (8) dapat diketahui, perusahaan akan memperoleh keuntungan ketika MPK lebih besar daripada biaya modal. Sebaliknya, perusahaan mengalami kerugian, apabila MPK lebih kecil daripada biaya modal.

Keputusan investasi perusahaan penyewaan untuk melakukan penambahan persediaan modal atau membiarkan modal yang ada terdepresiasi tergantung pada keuntungan yang akan diperoleh. Sementara itu, perubahan persediaan modal atau investasi neto tergantung pada MPK dan biaya modal. Perusahaan akan untung jika menambah persediaan modal, ketika MPK lebih besar daripada biaya modal. Namun, jika MPK lebih kecil dari biaya modal, perusahaan penyewaan akan membiarkan persediaan modalnya mengecil.

Perusahaan yang memiliki modal dan menggunakannya untuk kegiatan produksi akan memperoleh tambahan manfaat dari setiap unit modal (MPK) dan menanggung biaya modal. Sementara perusahaan yang memiliki dan menyewakan modalnya kepada perusahaan produksi akan menambah persediaan modalnya jika MPK melebihi biaya modal. Sehingga, tambahan persediaan modal dapat dituliskan sebagai berikut:

$$
\Delta K=I_{n}\left[r-\left(P_{K} / P\right)(i+\delta)\right]
$$

dimana $I_{n}($.$) merupakan fungsi yang menunjukkan respon insentif investasi terhadap$ jumlah investasi neto. Dengan demikian, fungsi investasi dapat diderivasi dari pengeluaran total atas investasi tetap bisnis. Sehingga, investasi tetap bisnis bergantung pada MPK, biaya modal, dan depresiasi:

5 Biaya modal riil (real cost of capital) adalah biaya membeli dan menyewakan unit modal yang diukur dalam unit output perekonomian. 


$$
I=I_{n}\left[r-\left(P_{K} / P\right)(i+\delta)\right]+\delta K
$$

Model investasi neoklasik pada Persamaan (10) menunjukkan bahwa, keputusan investasi ditentukan oleh tingkat bunga. Penurunan tingkat bunga riil akan mengurangi biaya modal. Selanjutnya, hal ini akan meningkatkan keuntungan yang diperoleh dari kepemilikan modal serta meningkatkan insentif dalam rangka mengakumulasikan modal. Demikian pula, kenaikan tingkat bunga riil akan meningkatkan biaya modal dan menyebabkan perusahaan memutuskan untuk menurunkan investasinya. Hal itu mengakibatkan kurva investasi miring ke bawah. Sementara meningkatnya MPK akan meningkatkan profitabilitas perusahaan atas investasi yang dilakukan, maka kurva investasi bergeser ke kanan (lihat Grafik 1).

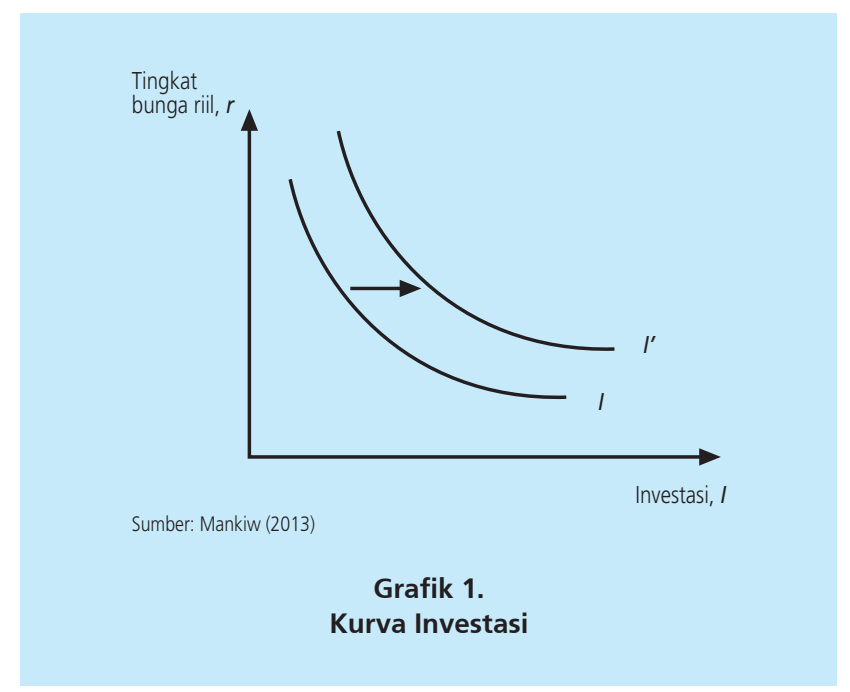

Apabila dilakukan penyesuaian persediaan modal secara terus-menerus, MPK berangsurangsur akan mendekati biaya modal. Ketika persediaan modal berada pada kondisi mapan, maka MPK dapat dituliskan sebagai berikut:

$$
\boldsymbol{r}=\left(\boldsymbol{P}_{\boldsymbol{K}} / \boldsymbol{P}\right)(\boldsymbol{i}+\boldsymbol{\delta})
$$

Dalam jangka panjang, MPK sama dengan biaya modal riil. Tercapainya kondisi mapan tergantung pada kecepatan perusahaan dalam menyesuaikan persediaan modalnya. Keputusan investor untuk berinvestasi didasarkan pada penghitungan tingkat pengembalian yang akan didapat. Dengan kata lain, investasi tergantung pada MPK ${ }^{6}$, yang merupakan suatu ukuran produktivitas satu unit modal yang ditanamkan. 


\subsection{Aliran Modal Internasional}

Investasi asing dibagi menjadi dua, yaitu investasi portofolio dan investasi asing langsung atau foreign direct investment (FDI). Investasi portofolio merupakan investasi dalam bentuk aset finansial, seperti obligasi, saham, serta surat hutang yang dinyatakan dalam bentuk mata uang nasional. Sementara itu, FDI merupakan investasi asing yang berwujud barang modal, tanah, dan persediaan (inventory). Investasi dalam bentuk FDI pada umumnya dilakukan oleh perusahaan multinasional (Multinational Corporations, MNCs) yang bergerak pada bidang pengelolaan sumber daya alam, manufaktur, dan jasa (Salvatore, 2013).

Pergerakan FDI yang masuk ke suatu negaradapat membawa potensi keuntungan maupun biaya bagi negara penerimanya. Potensi keuntungan tersebut, diantaranya kenaikan jumlah pekerja, upah, output, ekspor, maupun peningkatan penerimaan pajak. Hal ini karena peningkatan modal yang diimbangi kenaikan jumlah tenaga kerja dan penguasaan teknologi akan menambah output. Kegiatan produksi yang memiliki potensi ekspor akan menguntungkan negara lokasi produksinya dengan memperoleh mata uang asing untuk mendukung proses pembangunan. FDI yang mengalir ke suatu industri juga diharapkan dapat meningkatkan skala ekonomis industri tersebut. Selain itu, masuknya investasi asing berarti adanya kompetitor baru dalam industri yang diharapkan mampu melemahkan kekuatan monopoli domestik.

Efisiensi penggunaan modal sebagai dampak adanya investasi asing terjadi karena baik di negara yang berinvestasi (home country) maupun di negara tujuan investasi (host country) terjadi redistribusi pendapatan domestik. Hal ini diilustrasikan dalam Grafik 2 dengan asumsi terdapat dua faktor produksi, modal dan tenaga kerja yang digunakan secara penuh sebelum dan sesudah adanya aliran investasi luar negeri.

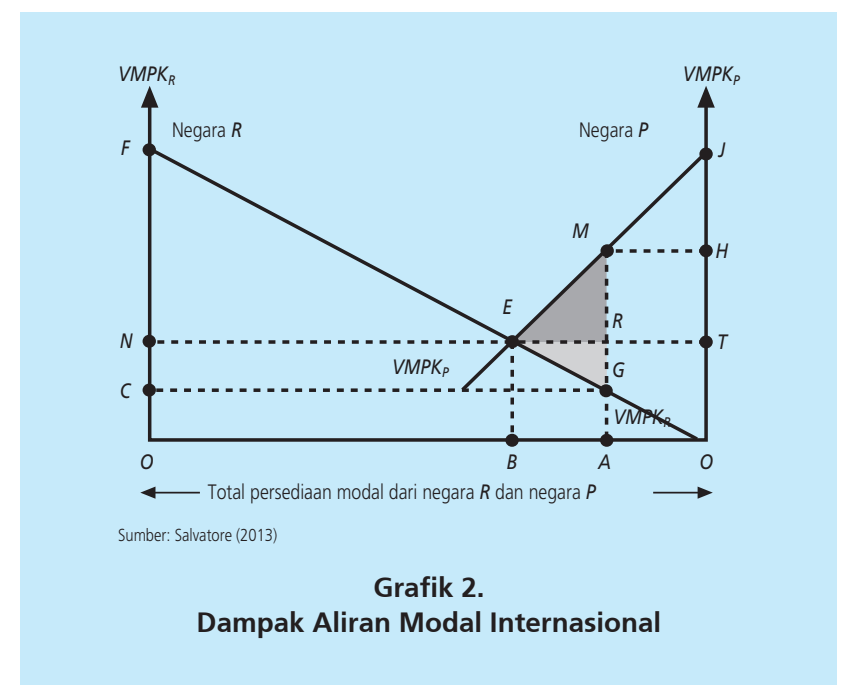


Meski berpotensi membawa keuntungan, pemerintah negara penerima perlu mengawasi dan mengontrol aliran FDI yang masuk. Apabila tidak dilakukan kontrol, aliran masuk FDI dikhawatirkan hanya akan menguntungkan beberapa pihak dan membebani perekonomian. Beberapa potensi biaya yang harus ditanggung oleh negara penerima FDI sebagai akibat dari tidak adanya kontrol investasi, diantaranya penurunan terms of trade ${ }^{7}$. Bagi negara berkembang, aliran masuk FDI dapat mengurangi tingkat tabungan domestik. Selain itu, perusahaan asing yang berinvestasi dapat membiayai proyeknya dengan meminta pinjaman dana dari negara penerima aliran FDI. Akibatnya, suku bunga di negara tersebut naik dan investasi domestik akan turun. Dampak lain dari adanya aliran modal internasional ialah berubahnya posisi neraca pembayaran. Selain itu, aliran masuk FDI ke suatu negara juga berisiko meningkatkan pengangguran, berkurangnya perhatian terhadap perkembangan pendidikan dan keahlian, munculnya monopoli industri, serta hilangnya kontrol terhadap kebijakan dalam negeri (Appleyard, Field, dan Cobb, 2010).

\subsection{Teori Heckscher-Ohlin}

Teori Heckscher-Ohlin ( $\mathrm{H}-\mathrm{O})$ menekankan perbedaan faktor pemberian alam (factor endowment) serta harga-harga faktor produksi dengan asumsi kedua negara memiliki teknologi dan selera yang sama. Model yang dikembangkan $\mathrm{H}-\mathrm{O}$ ialah "2×2x2," artinya dua negara (R dan P) memproduksi dua jenis barang yang berbeda (X-komoditi padat karya dan $\mathrm{Y}$-komoditi padat modal) menggunakan dua faktor input ( $\mathrm{K}$ dan $\mathrm{L}$ ). Hal tersebut sesuai dengan salah satu asumsi dasar teori $\mathrm{H}-\mathrm{O}$ yang digunakan untuk menjelaskan perbedaan di antara negara-negara yang melakukan perdagangan internasional. Selain itu, kedua negara berproduksi pada kondisi constant return to scale, berlaku decreasing marginal productivity untuk masing-masing input, dan menghadapi pasar persaingan sempurna. Apabila faktor-faktor input tidak bergerak secara bebas di antara kedua negara, maka terjadi tukar-menukar barang. Dengan demikian, fungsi produksinya:

$$
\begin{aligned}
& F_{R}^{X}(K, L)=F_{P}^{X}(K, L) \\
& F_{R}^{Y}(K, L)=F_{P}^{Y}(K, L)
\end{aligned}
$$

dengan menunjukkan fungsi produksi dari komoditi $\boldsymbol{j} \in\{\boldsymbol{X}, \boldsymbol{Y}\}$ dengan input (K), (L) di negara $\boldsymbol{i} \in\{\boldsymbol{R}, \boldsymbol{P}\}$.

7 Terms of trade didefinisikan sebagai rasio antara harga ekspor dan impor. 


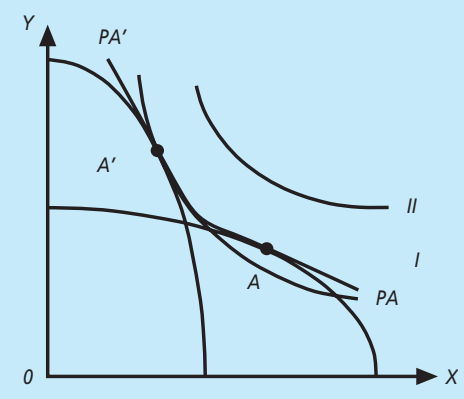

Sumber: Salvatore (2013)

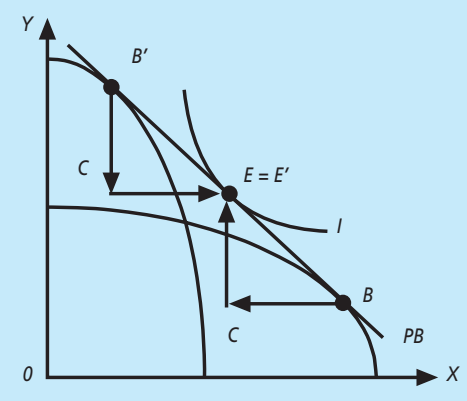

Sumber: Salvatore (2013)

Grafik 3.

Model Heckscher-Ohlin

Teori H-O secara singkat dijelaskan dalam dua teorema (Salvatore, 2013). Pertama, teorema $\mathrm{H}-\mathrm{O}(\mathrm{H}-\mathrm{O}$ theorem) yang memprediksi pola perdagangan. Teorema ini menganggap, bahwa secara relatif setiap negara akan mengekspor komoditi dengan faktor produksi berlimpah dan murah, serta mengimpor komoditi yang faktor produksinya relatif langka dan mahal. Kedua, teorema penyamaan harga faktor produksi (factor-price equalization theorem) atau disebut pula teorema H-O-S (Heckscher-Ohlin-Samuelson). Teorema H-O-S menjelaskan dampak perdagangan internasional terhadap harga input. Teorema ini menganggap perdagangan akan menghapuskan atau mengurangi perbedaan harga absolut maupun harga relatif faktor produksi pada setiap negara.

\subsection{Paradoks Lucas}

Robert E. Lucas Jr. (1990) menemukan sebuah paradoks dari teori neoklasik yang memprediksi modal mengalir "downhill" dari negara yang memiliki kelimpahan modal (capital abundant) ke negara yang kekurangan modal (capital scare). Menurut Lucas, yang terjadi adalah sebaliknya. Akan tetapi jika output per tenaga kerja di antara kedua negara berbeda, hal ini dikarekan adanya perbedaan modal per tenaga kerja. Untuk menjelaskan hal tersebut, Lucas mengasumsikan perekonomian dalam kondisi terbuka kecil serta input produksi ialah modal (K) dan tenaga kerja (L). Selain itu, produksi dilakukan pada constant return to scale seperti halnya neoklasik, sehingga:

$$
y=f(k)=A k^{\beta}
$$


dengan $y$ adalah output atau pendapatan per tenaga kerja, dan $k$ adalah modal per tenaga kerja. Kemudian, MPK (r) diturunkan dari Persamaan (13) dengan, sehingga:

$$
\begin{aligned}
\boldsymbol{r} & =\boldsymbol{A} \boldsymbol{\beta} \boldsymbol{k}^{\boldsymbol{\beta}-\mathbf{1}} \\
& =\boldsymbol{A} \boldsymbol{\beta}(\boldsymbol{y} / \boldsymbol{A})^{(\boldsymbol{\beta}-\mathbf{1}) / \boldsymbol{\beta}} \\
& =\boldsymbol{\beta} \boldsymbol{A}^{\mathbf{1} / \boldsymbol{\beta}} \boldsymbol{y}^{(\boldsymbol{\beta}-\mathbf{1}) / \boldsymbol{\beta}}
\end{aligned}
$$

Apabila model tersebut terbukti, pasar modal internasional menjadi bebas dan sempurna, negara akan menghadapi berbagai tingkat pengembalian modal. Sehingga modal akan mengalir dari negara kaya ke negara miskin. Namun demikian, Lucas berpendapat, asumsi penggunaan teknologi yang sama dan terjadinya perdagangan karena perbedaan factor endowments tidak tepat. Untuk menjelaskan hal tersebut Lucas menggunakan tiga asumsi, yaitu (1) perbedaan modal manusia (human capital), (2) manfaat eksternal dari modal manusia (external benefits of human capital), dan (3) ketidaksempurnaan pasar modal (capital market imperfecions).

\subsubsection{Perbedaan Modal Manusia (Human Capital)}

Dalam model neoklasik, menurut Lucas, input tenaga kerja yang digunakan mengabaikan perbedaan kualitas tenaga kerja atau modal manusia tiap tenaga kerja. Untuk itu, Lucas mengggunakan ukuran perbedaan modal manusia berdasarkan studi Anne O. Krueger (1968) yang menggabungkan informasi mengenai tenaga kerja tingkat pendidikan, usia, dan sektor untuk melihat pengaruhnya terhadap produktivitas yang diukur dengan pendapatan relatif.

Apabila diasumsikan masing-masing negara memiliki produktivitas yang sama, pengaruh modal manusia terhadap MPK ialah:

$$
\begin{aligned}
r_{R} & =\beta A^{1 / \beta} y_{R}^{(\beta-1) / \beta} \\
r_{P} & =\beta A^{1 / \beta} y_{P}^{(\beta-1) / \beta} \\
\leftrightarrow r_{P} & =r_{R} \cdot\left(y_{P} / y_{R}\right)^{(\beta-1) / \beta}
\end{aligned}
$$

dimana adalah tingkat suku bunga di negara kaya, adalah tingkat suku bunga di negara miskin, dan y merupakan tingkat output yang dihasilkan kedua negara. Persamaan (15) tersebut dapat digunakan untuk membandingkan MPK antara negara miskin dengan negara kaya. Namun demikian, menurut Lucas, diabaikannya modal manusia bukan satu-satunya alasan mengapa modal tidak mengalir dari negara kaya ke negara miskin (Lucas, 1990; Pogoda, 2012).

8 Factor Endowments and Per Capita Income Differences Among Countries - The Economic Journal Sept 1968, 78 (311), hlm. 641659. 


\subsubsection{Manfaat Eksternal dari Modal Manusia (External Benefits of Human Capital)}

Perbedaan output yang dihasilkan tiap negara mungkin dikarenakan adanya perbedaan tingkat teknologi ${ }^{9}(A)$. Dengan demikian, fungsi produksinya dapat ditulis sebagai berikut:

$$
\boldsymbol{y}=\boldsymbol{f}(\boldsymbol{k}, \boldsymbol{h})=A \boldsymbol{k}^{\beta} \boldsymbol{h}^{\gamma}
$$

dengan $y$ adalah output atau pendapatan per tenaga kerja, $k$ adalah modal per tenaga kerja, dan $h$ adalah modal manusia. Sehingga apabila modal manusia berpengaruh positif terhadap tingkat pengembalian modal, maka modal yang mengalir ke negara dengan modal manusia rendah juga sedikit. Sementara itu, formula MPK menjadi:

$$
r=\beta A^{1 / \beta} y^{(\beta-1) / \beta} h^{\gamma / \beta}
$$

Dalam mengestimasi parameter , Lucas menggunakan metode perbandingan produktivitas Edward Denison (1962) $)^{10}$ dan mengaplikasikannya pada Persamaan (15) dengan metode estimasi cross-country Krueger hingga diperoleh perkiraan tingkat pengembalian modal relatif yang baru. Hal ini sesuai dengan yang dituliskan Lucas (1988)11 , bahwa $\vartheta$ digambarkan sebagai tingkat pertumbuhan modal manusia dan adalah tingkat perubahan teknologi (eksogen). Denison mengestimasi $\vartheta$ dan $\beta$ sebagai produktitivas, sedang Krueger sebagai persediaan modal manusia relatif, kemudian disusun kembali hingga diperoleh nilai estimasi dari $\gamma$. Hasilnya, rasio tingkat pengembalian antara negara miskin dan negara kaya, menurut Lucas, berlaku pada kasus peningkatan modal manusia.

\subsubsection{Ketidaksempurnaan Pasar Modal (Capital Market Imperfections)}

Perbedaan MPK antar negara berimplikasi terjadinya arus barang modal pada periode tertentu. Namun demikian, tak ada arus modal tanpa biaya dan pasar yang sepenuhnya kompetitif karena adanya ketidakstabilan politik di dunia. Hal tersebut diringkas dengan istilah "risiko politik" dan menjadi salah satu faktor yang menentukan aliran modal. Sebagai contoh, beberapa negara kaya memiliki negara jajahan, hal ini dijelaskan Lucas dalam melihat keputusan imperialis dengan karakteristik berikut:

$$
\max _{k}\left\{f(k)-\left[f(k)-k f^{\prime}(k)\right]-r_{w} k\right\}
$$

dengan $r_{w}$ adalah tingkat pengembalian modal dunia, dan kondisi orde pertama terhadap $k$ ialah:

9 Lucas mengartikan teknologi sebagai rata-rata tingkat modal manusia tiap tenaga kerja.

10 The Sources of Economic Growth in the United States, New York: Committee for Economic Development, 1962.

11 On the Mechanics of Economic Development- Journal of Monetary Economics, January 1988, 22, hlm. 3-32. 


$$
\begin{aligned}
F O C[k]: & f^{\prime}(k)+k f^{\prime \prime}(k)-r_{w}=0 \\
& \leftrightarrow r_{w}=f^{\prime}(k)+k f^{\prime \prime}(k)=\beta f^{\prime}(k)=\beta r
\end{aligned}
$$

Persamaan tersebut menunjukkan hubungan linear antara tingkat pengembalian modal dunia dan dalam negeri. Menurut Lucas, perbedaan suku bunga dikarenakan adanya ketidaksempurnaan pasar, seperti halnya negara kaya dan miskin yang tidak akan bersepakat perihal pinjam-meminjam. Ketidaksempurnaan pasar inilah yang tidak dijelaskan dalam model neoklasik, sehingga modal tidak bergerak dari negara kaya ke negara miskin (Lucas, 1990; Pogoda, 2012).

\section{METODOLOGI}

Penelitian ini menggunakan data panel, dengan sampel lima negara anggota ASEAN periode 2000-2011. Untuk menjawab pertanyaan penelitian digunakan analisis regresi data panel dengan metode estimasi fixed effect model (FEM). Metode tersebut dipilih karena FEM mampu memberikan hasil estimasi yang mengizinkan individu (cross-section) untuk memiliki intersepnya sendiri. Selain itu, FEM memungkinkan analisis mengenai heterogenitas masingmasing individu dengan memberikan dummy (Baltagi, 2008) sehingga dapat menggambarkan perbedaan aliran modal di masing-masing negara.

Dalam penelitian ini, digunakan model empiris sebagai berikut:

$$
\text { CAP_INFLOW }_{i j, t}=f\left(\text { MPK }_{i j t}, G_{\text {IPPC }}, \text { SCHOOL }_{i j t}, \text { TFP }_{i j t}, \text { INST }_{i j t}\right)
$$

Berdasarkan pada Persamaan (20), variabel MPK dan GDP per kapita mewakili model neoklasik. Sementara itu variabel rata-rata lama sekolah, pertumbuhan TFP, dan risiko politik mewakili model Lucas. Dengan demikian, model persamaan regresinya dapat dituliskan sebagai berikut:

$$
\begin{aligned}
\text { CAP }_{\text {INFLOW }}, i, t, t & \beta_{0 i j}+\beta_{1} M P K_{i j, t}+\beta_{2} G{ }^{2} P P C_{i j, t}+\beta_{3} S C H O O L_{i j, t}+\beta_{4} T F P_{i j, t}+ \\
& \beta_{5} I N S T_{i j, t}+\varepsilon_{i j, t}
\end{aligned}
$$

Model umum dari metode estimasi FEM dengan individual effect adalah:

$$
Y_{i j, t}=\alpha_{1}+\alpha_{2}+\alpha \sum D_{i j}+\beta_{2} X_{2 i j, t}+\mu_{i j, t}
$$

dengan $\mathrm{Y}$ adalah variabel dependen, $\mathrm{D}$ adalah dummy individu, dan $\mathrm{X}$ adalah variabel independen. Karena penelitian ini bertujuan untuk mengetahui aliran modal antar negara dengan mempertimbangkan perbedaan kondisi di negara asal maupun negara tujuan, maka variabel independennya dinyatakan dalam bentuk relatif, sehingga secara matematis dapat dituliskan sebagai berikut: 


$$
\text { CAP_INFLOW }_{i j, t}=\beta_{0}+\beta_{1}\left(\frac{x_{1, i}}{x_{1, j}}\right)_{t}+\cdots+\beta_{5}\left(\frac{X_{5, i}}{X_{5, j}}\right)_{t}+\sum_{i=n} \beta_{6} D_{i j}+\mu_{i j, t}
$$

Dengan demikian, model utama pada penelitian ini dapat dituliskan sebagai berikut:

$$
\begin{aligned}
& \text { CAP_INFLOW } \beta_{i j, t}= \\
& \beta_{0}+\beta_{1}\left(\frac{M P K_{i}}{M P K_{j}}\right)_{t}+\beta_{2}\left(\frac{G D P P C_{i}}{G D P P C_{j}}\right)_{t}+\beta_{3}\left(\frac{S C H O O L_{i}}{S C H O O L_{j}}\right)_{t}+ \\
& \beta_{4}\left(\frac{T_{F P_{i}}}{\left.T_{F P}\right)_{j}}+\beta_{5}\left(\frac{I N S T_{i}}{I N S T_{j}}\right)_{t}+\sum_{i=n} \beta_{6} D_{i j}+\mu_{i j, t}\right.
\end{aligned}
$$

Persamaan (24) merupakan persamaan model regresi yang akan digunakan dalam penelitian ini. Bentuk rasio dipilih karena variabel dependen, yakni aliran FDI dinyatakan dalam net basis ${ }^{12}$, sehingga besaran aliran FDI dalam penelitian ini ada yang bernilai negatif. Apabila model dinyatakan dalam bentuk logaritma natural, maka harus dilakukan penambahan konstanta pada variabel aliran FDI. Selain itu, jika dinyatakan dalam bentuk logaritma natural, model akan mengalami permasalahan dengan degree of freedom.

\section{HASIL DAN PEMBAHASAN}

\subsection{Analisa Deskriptif Pergerakan Modal di ASEAN}

ASEAN merupakan pasar dengan 600 juta penduduk atau sekitar 9\% dari total populasi dunia. Pendapatan per kapita di kawasan ini mencapai 3.600 USD pada tahun $2011^{13}$. Hal tersebut menjadikan ASEAN sebagai pasar yang potensial. Selain itu, negara-negara ASEAN juga telah sepakat untuk mewujudkan aliran modal yang lebih bebas secara bertahap sesuai dengan tingkat pembangunan ekonomi dan kesiapan sistem keuangan masing-masing anggota (Djaafara dkk, 2012).

Beberapa upaya untuk menciptakan kawasan investasi yang bebas dan transparan, sehingga dapat menarik serta meningkatkan arus FDI intra-ASEAN dan ekstra-ASEAN secara berkesinambungan diantaranya Framework Agreement on the ASEAN Investment Area (FAAIA) dan Investment Guarantee Agreement (IGA). Pada tahun 2008, kedua jenis kesepakatan investasi ASEAN tersebut disempurnakan dengan penandatanganan ASEAN Comprehensive Investment Agreement (ACIA). ACIA memuat empat pilar utama, yaitu liberalisasi, proteksi, fasilitasi, dan promosi. Selain itu, ACIA didasarkan pada prinsip keterbukaan, perlakuan yang sama, dan mengadopsi international best practices. Dengan demikian, ASEAN diharapkan menjadi kawasan yang kompetitif untuk menarik FDI serta tujuan akhir integrasi ekonomi dalam ASEAN Economic Community (AEC) dapat terealisasi (Kementerian Luar Negeri RI, 2012).

12 United Nations Conference on Trade and Development. FDI Flows. http://unctad.org/en/Pages/DIAE/Investment\%20and\%20 Enterprise/FDI_Flows.aspx diakses Senin, 13 Mei 2015 pukul 14.20 WIB.

13 Invest in ASEAN http://investasean.asean.org/index.php/page/view/reasons-for-investing diakses Minggu, 26 April 2015 pukul 13:45 WIB. 
Sejak dorongan integrasi ekonomi di ASEAN dilakukan, FDI yang mengalir ke sub-wilayah meningkat. Menurut Hsu (2013), kenaikan aliran FDI ke ASEAN secara keseluruhan dilatar belakangi oleh tiga hal. Pertama, upaya bersama anggota ASEAN menuju integrasi ekonomi yang lebih besar dan liberalisasi dalam jangka waktu tertentu termasuk pembentukan ASEAN Free Trade Area (AFTA) dan FA-AIA menjadi daya tarik kawasan. Kedua, Singapura bersama negara-negara ASEAN lainnya telah melakukan berbagai langkah liberalisasi perdagangan dan insentif deregulasi setelah pembentukan World Trade Organization (WTO) tahun 1995. Ketiga, Plaza Accord tahun 1985 memperlihatkan apresiasi yang signifikan dari Yen Jepang, sehingga FDI ke ASEAN meningkat.

Pada tahun 2000 sampai 2011, secara umum, aliran FDI yang masuk ke setiap negara ASEAN 5, baik yang berasal dari intra-ASEAN maupun ekstra-ASEAN, fluktuatif (lihat Grafik 4). Aliran FDI yang masuk ke Singapura pada periode tersebut rata-rata adalah $26.738,54$ juta USD. Sementara itu, rata-rata aliran FDI yang masuk ke Thailand sebesar 6.503,89 juta USD, ke Malaysia 5.260,56 juta USD, dan yang masuk ke Indonesia adalah 5.191,70 juta USD. Sedangkan aliran FDI ke Philipina 1.623,54 juta USD. Apabila dilihat dari negara penerima aliran FDI, Singapura merupakan negara yang menerima aliran FDI paling besar. Pada tahun 2011, aliran FDI yang masuk ke Singapura sebesar 48.474,50 juta USD dari total 97.538,12 juta USD yang masuk ke ASEAN. Dari jumlah tersebut, FDI yang diterima Singapura yang berasal dari negara-negara kawasan Asia Tenggara ialah 2.386,20 juta USD.

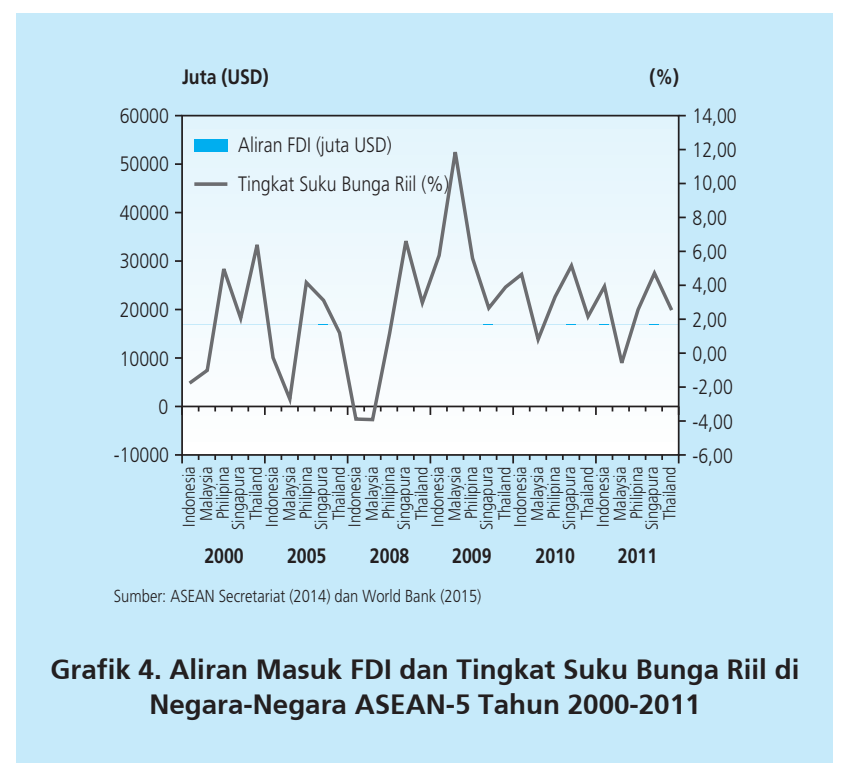


Sementara itu, tingkat suku bunga riil di setiap negara ASEAN 5 dari tahun 2000 sampai 2011 fluktuatif. Pada periode tersebut, rata-rata tingkat suku bunga riil di Singapura adalah 4,08\%. Sementara itu, rata-rata tingkat suku bunga riil Indonesia 3,72\%, Thailand 3,56\%, dan Malaysia 1,95\%. Sedangkan Philipina, rata-rata tingkat suku bunga riilnya merupakan yang tertinggi di antara negara-negara ASEAN 5, yaitu 4,45\%.

Apabila dilihat berdasarkan sektor tujuan investasi, aliran masuk FDI ke ASEAN 5 sebagian besar diinvestasikan ke industri-industri yang didukung oleh sumber daya di negara-negara tersebut ${ }^{14}$. Salah satunya Indonesia, yang pada tahun 2011 menarik aliran FDI ke sektor primer, seperti pertambangan. Hal ini menunjukkan bahwa Indonesia merupakan negara yang memiliki sumber daya alam melimpah (natural resource endowment). Pada tahun 2011, sebanyak 63\% aliran FDI yang masuk ke Indonesia diinvestasikan pada industri perminyakan dan pertambangan serta manufaktur. Pemerintah Indonesia juga terus berupaya untuk memperbaiki iklim investasi di negaranya. Tahun 2010, pemerintah mengeluarkan Peraturan Presiden Nomor 36 untuk mengatur liberalisasi 17 sub-sektor bisnis, diantaranya pertanian, kehutanan, kelautan dan perikanan, energi dan sumber daya mineral, serta manufaktur (Tambunan, 2013).

Aliran FDI yang bergerak ke industri manufaktur terkonsentrasi di industri elektronik dan otomotif. Beberapa negara ASEAN bahkan telah menjadi pusat produksi dan link utama dalam rantai nilai dan pasokan global di industri tersebut ${ }^{15}$. Di Malaysia, industri penerima aliran FDI utama ialah industri manufaktur. Pemerintah Malaysia juga terus berupaya untuk melakukan liberalisasi di sektor manufaktur dan jasa, mempromosikan wilayah ekonomi baru (new economic key areas), serta menciptakan kondisi perekonomian yang kuat (Rajah dan Govindaraju, 2013). Industri manufaktur Thailand juga menerima aliran FDI terbesar yaitu hampir 55\% di tahun 2011. Terkonsentrasinya aliran FDI yang masuk ke ASEAN pada industri manufaktur sejalan dengan FA-AIA. Dalam FA-AIA, negara-negara anggota sepakat untuk membuka investasi, terutama di sektor manufaktur, baik yang berasal dari intra-ASEAN maupun ekstra-ASEAN. Sementara itu, sektor perdagangan dan perniagaan serta sektor jasa termasuk industri keuangan mendominasi aliran FDI yang masuk ke Singapura. Di Singapura, sektor jasa secara keseluruhan menerima mayoritas FDI yang masuk pada tahun 2011.

14 ASEAN Investment Report 2012: The Changing FDI Landscape, hlm. 4.

$15 \mathrm{lbid}, \mathrm{hlm} .6$. 


\begin{tabular}{|c|c|c|c|c|c|}
\hline \multicolumn{6}{|c|}{$\begin{array}{c}\text { Tabel } 2 \\
\text { Aliran Masuk FDI ke Negara-Negara ASEAN } 5 \\
\text { Berdasarkan Industri Tahun } 2011 \text { (dalam juta USD) }\end{array}$} \\
\hline Negara Tujuan Industri & Indonesia & Malaysia & Philipina & Singapura & Thailand \\
\hline Pertanian, Perikanan, dan Kehutanan & 344,4 & 40,5 & 4,0 & 0,3 & 10,9 \\
\hline Perminyakan dan Pertambangan & $3.882,0$ & $2.410,9$ & $-240,4$ & 1,4 & 296,2 \\
\hline Manufaktur & $8.157,0$ & $5.317,7$ & 102,3 & $3.222,2$ & $4.296,2$ \\
\hline Konstruksi & 411,4 & 34,7 & 28,1 & 284,5 & $-79,2$ \\
\hline Perdagangan dan Perniagaan & $2.881,8$ & $1.154,8$ & 33,5 & $13.112,2$ & 321,6 \\
\hline Keuangan & 558,5 & $1.797,2$ & 211,9 & $8.876,3$ & $1.337,2$ \\
\hline Perumahan & 587,3 & 161,6 & 118,7 & $8.447,4$ & $1.110,1$ \\
\hline Jasa-jasa & $1.953,7$ & $1.012,8$ & 275,5 & $3.779,2$ & 413,8 \\
\hline Lainnya & 365,5 & 70,7 & $-20,5$ & 0,0 & 71,3 \\
\hline Sub Total & $19.241,6$ & $12.000,9$ & 513,0 & $37.723,5$ & $7.778,1$ \\
\hline Tidak Terspesifikasi & - & - & 749,0 & $26.273,7$ & - \\
\hline Total & $19.241,6$ & $12.000,9$ & $1.262,0$ & $63.997,2$ & $7.778,1$ \\
\hline
\end{tabular}

\subsection{Aliran FDI Intra-ASEAN 5}

Pada penelitian ini, aliran FDI intra-ASEAN 5 diasumsikan sepenuhnya terjadi karena capital mobility creation. Selain itu, negara-negara ASEAN 5 menutup diri dari negara lain di luar kawasan. Asumsi tersebut ditujukan untuk mengetahui determinan aliran FDI di ASEAN 5. Hasil estimasi regresi pada studi kasus intra-ASEAN dirangkum dalam Tabel 3. Kolom downhill dan uphill menunjukkan estimasi untuk masing-masing kasus.

Pada studi kasus Singapura sebagai negara asal FDI, keputusan untuk berinvestasi di Indonesia, Malaysia, Philipina, dan Thailand dipengaruhi oleh GDP per kapita, rata-rata lama sekolah, dan kualitas kelembagaan. Inferensi statistik pada kasus ini dilakukan dengan menganggap variabel-variabel independen di Singapura konstan. Hasil estimasi menunjukkan, bahwa GDP per kapita berpengaruh negatif terhadap aliran FDI masuk. Hal ini berarti bahwa semakin kecil GDP per kapita Indonesia, Malaysia, Philipina, dan Thailand maka semakin besar aliran FDI yang masuk ke negara tersebut. 


\begin{tabular}{|c|c|c|}
\hline \multicolumn{3}{|c|}{$\begin{array}{c}\text { Tabel } 3 \\
\text { Determinan Aliran FDI Intra-ASEAN } 5\end{array}$} \\
\hline \multicolumn{3}{|c|}{ Variabel Dependen: Aliran FDI bilateral, 2000 - 2011 (Cap_Inflow ${ }_{\mathrm{ij}, \mathrm{t}}$ ) } \\
\hline & $\begin{array}{l}\text { Downhill: Singapura - } \\
\text { Source Country }\end{array}$ & $\begin{array}{l}\text { Uphill: Singapura - } \\
\text { Host Country }\end{array}$ \\
\hline \multirow[t]{2}{*}{ Konstanta } & 4662,27 & 3691,29 \\
\hline & $(0,5663)$ & $(1,9642)^{* *}$ \\
\hline \multirow[t]{2}{*}{ Tingkat Suku Bunga Riil (MPK) } & $-3,97271$ & 69,6647 \\
\hline & $(-0,2207)$ & $(1,4384)^{*}$ \\
\hline \multirow[t]{2}{*}{ GDP per Kapita } & $-369,993$ & 9635,13 \\
\hline & $(-1,3311)^{*}$ & $(0,4370)$ \\
\hline \multirow[t]{2}{*}{ Rata-rata Lama Sekolah } & 8846,25 & $-5564,78$ \\
\hline & $(2,4729)^{\star \star *}$ & $(-3,8188)^{\star \star *}$ \\
\hline \multirow[t]{2}{*}{ Pertumbuhan TFP } & $-8,08940$ & 83,1659 \\
\hline & $(-0,3547)$ & $(1,6346)^{*}$ \\
\hline \multirow[t]{2}{*}{ Risiko Politik } & $-3553,08$ & 1662,90 \\
\hline & $(-2,2057)^{\star *}$ & $(1,3023)^{*}$ \\
\hline $\mathrm{R}^{2}$ & 0,4553 & 0,5113 \\
\hline Adjusted. $\mathrm{R}^{2}$ & 0,3436 & 0,4111 \\
\hline F-statistik & 4,0763 & 5,1017 \\
\hline DW-statistik & 1,4542 & 1,4583 \\
\hline \multicolumn{3}{|c|}{$\begin{array}{l}\text { Keerangan: Angka bercetak miring dan dalam kurung merupakan nilai t-statistik. Nilai t pada model Singapura-Source Country } \\
\text { telah disesuaikan dengan Newey-West standard error. }{ }^{* \star *} \text { signifikan pada } \alpha=0,01 ;{ }^{* \star} \text { signifikan pada } \alpha=0,05 ;{ }^{*} \\
\text { signifikan pada } \alpha=0,1\end{array}$} \\
\hline
\end{tabular}

Hasil uji empiris menunjukkan, bahwa aliran FDI dari Singapura bergerak menuju ke negara dengan GDP per kapita rendah (kelompok negara berkembang). Hal ini bertolak belakang dengan temuan Root dan Ahmed (dalam Appleyard, Field, dan Cobb, 2010). Menurut Root dan Ahmed, salah satu variabel yang menentukan besar kecilnya aliran FDI ialah GDP per kapita. Aliran FDI yang mengalir ke negara dengan GDP per kapita tinggi jumlahnya besar. Karena tingginya pendapatan per kapita menunjukkan tingginya kemampuan konsumen dalam membeli barang-barang produksi industri manufaktur.

Karakteristik aliran FDI dari Singapura tersebut tidak terlepas dari kebijakan pemerintah Singapura untuk mendorong investasi di negara-negara berpendapatan rendah. Hal ini karena kecilnya pasar domestik dan tingginya biaya tenaga kerja di Singapura. Selain itu, pemerintah juga membuat kebijakan untuk mempromosikan "an external wing" Singapura. Dalam strategi regionalisasinya (Government's regionalization strategy), pemerintah Singapura memberikan fasilitas pada investor-investor lokal yang akan berinvestasi di luar negeri. Pemerintah Singapura juga terjun langsung dalam upaya menyiapkan proyek industri sektor manufaktur di negara tujuan investasinya (host country), seperti Indonesia. Pada waktu yang bersamaan, pemerintah 
Singapura mendorong FDI dari negara-negara maju untuk ditanamkan di negaranya, dalam rangka memfasilitasi akuisisi teknologi baru. Perekonomian Singapura pun beralih, dari yang mulanya terlibat dalam industri manufaktur padat karya (tahun 1960-an) menjadi pusat penghasil barang-barang dengan nilai tambah tinggi dan berbagai layanan/jasa di tahun 2000-an (Ellingsen, Likumahuwa, dan Nunnenkamp, 2006; Blomqvist, 2002; Yeung, 1999; Hsu, 2013).

Faktor lain yang menentukan aliran FDI dari Singapura ke negara ASEAN 5 lainnya adalah kualitas kelembagaan. Singapura dalam berinvestasi merujuk pada negara dengan risiko politik rendah. Pasalnya, pada kasus ini kualitas kelembagaan berpengaruh negatif terhadap aliran modal. Hal ini berarti semakin tinggi risiko politik di negara tujuan, aliran FDI yang masuk ke negara tersebut semakin kecil. Menurut AKV (2007), salah satu faktor penentu aliran modal yang paling penting ialah kualitas kelembagaan. Hal ini dikarenakan, dalam berinvestasi perusahaan asing mempertimbangkan berbagai kebijakan (policy framework) dan sikap pemerintah negara tujuan (host country). Di Indonesia, misalnya, beberapa ketidakpastian terkait dengan pelaksanaan otonomi daerah dan tingginya biaya untuk menjalankan bisnis karena tidak memadainya infrastuktur, ketatnya peraturan ketenagakerjaan, dan korupsi menjadi salah satu faktor yang menentukan tinggi rendahnya aliran FDI yang masuk (Tambunan, 2013).

Hasil uji empiris juga memperlihatkan bahwa rata-rata lama sekolah di negara tujuan menjadi pertimbangan Singapura dalam mengalokasikan FDI-nya ke ASEAN. Singapura mengalirkan FDI nya ke negara-negara dengan rata-rata lama sekolah tinggi. Pada penelitian ini, rata-rata lama sekolah negara ASEAN 5 lainnya lebih rendah jika dibandingan dengan Singapura. Dengan demikian, aliran FDI dari Singapura ke Indonesia, Malaysia, Philipina, dan Thailand tergolong rendah, maka investasi pada industri yang membutuhkan dukungan sumber daya manusia dan teknologi tinggi dipertahankan di negaranya. Di Malaysia misalnya, salah satu alasan perlambatan aliran masuk FDI ialah kurangnya keterampilan dan pengusaan teknologi yang dimiliki para tenaga kerja (Rajah dan Govindaraju, 2013). Penelitian ini mengindikasikan bahwa FDI yang ditanamkan Singapura pada kegiatan produksi di industri dengan humancapital intensive.

Selain itu, pada kasus Singapura sebagai negara asal investasi, berdasarkan uji empiris variabel independen secara simultan mempengaruhi aliran FDI. Sementara, variasi variabelvariabel independen mampu menjelaskan 45,53\% aliran FDI dari Singapura ke negara ASEAN 5 lainnya. Pada kasus ini estimasi dilakukan dengan menetapkan aliran FDI dari Singapura ke Indonesia (SGP_IDN) sebagai benchmark. Hal ini dikarenakan aliran FDI dari Singapura ke Indonesia merupakan yang terbesar di antara negara ASEAN 5 lainnya. Hasil estimasi menunjukkan bahwa tidak ada satu pun variabel dummy yang signifikan.

Pada kasus Singapura sebagai negara tujuan investasi menunjukkan bahwa keputusan Indonesia, Malaysia, Philipina, dan Thailand untuk mengalirkan FDI ke Singapura dipengaruhi oleh tingkat pengembalian modal, rata-rata lama sekolah, pertumbuhan TFP, dan kualitas 
kelembagaan. Pada kasus ini, dalam melakukan inferensi statistik Singapura dianggap konstan. Tingkat suku bunga riil berpengaruh positif terhadap aliran FDI. Artinya, semakin tinggi tingkat suku bunga riil di negara asal investasi maka semakin besar aliran FDI yang keluar dari negara tersebut. Hal ini memberikan gambaran bahwa, sekalipun tingkat suku bunga riil di negara ASEAN 5 lainnya tinggi, investor lebih memilih untuk menanamkan FDI-nya ke Singapura dengan mempertimbangkan kualitas kelembagaan, rata-rata lama sekolah, dan pertumbuhan TFP.

Selain itu, besarnya aliran FDI negara ASEAN 5 lainnya ke Singapura juga didorong rendahnya risiko politik. Pada kasus ini kualitas kelembagaan berpengaruh positif terhadap aliran modal. Dengan demikian, semakin tinggi risiko politik di negara asal maka semakin besar aliran FDI yang masuk ke Singapura. Hal ini menunjukkan jika Singapura memiliki kualitas kelembagaan yang baik sehingga investor akan memperoleh jaminan risiko politik yang mungkin terjadi. Indeks risiko politik ${ }^{16}$ di Singapura tahun 2011 mencapai angka 84,04. Angka indeks tersebut berarti, bahwa pada tahun 2011 Singapura memiliki kualitas kelembagaan yang baik apabila dibandingkan dengan negara ASEAN 5 lainnya; Malaysia $(72,58)$, Philipina $(62,17)$, Indonesia (59), dan Thailand $(57,17)$. Hal ini dikarenakan semakin tinggi angka indeks, semakin rendah risiko politiknya.

Faktor lain yang dipertimbangkan oleh investor dalam menanamkan FDI-nya ke Singapura ialah modal manusia. Hasil penelitian ini menunjukkan, rata-rata lama sekolah berpengaruh negatif terhadap aliran modal. Sehingga semakin tingggi rata-rata lama sekolah di negara asal maka semakin kecil aliran FDI yang keluar dari negara tersebut menuju Singapura. Pada tahun 2011, rata-rata lama sekolah di Singapura merupakan yang tertinggi diantara negara-negara ASEAN 5. Data United Nation Development Programme (UNDP) menunjukkan, pada tahun 2011, rata-rata lama sekolah di Singapura 10,1 tahun, sementara Malaysia 9,53 tahun, Philipina 8,88 tahun, Indonesia 7,51 tahun, dan Thailand 7,32 tahun.

Sementara itu, pertumbuhan TFP juga berpengaruh positif. Artinya, semakin tinggi pertumbuhan TFP di negara asal FDI, semakin besar pula aliran FDI yang masuk ke Singapura. Meski demikian, hubungan antara aliran FDI dan pertumbuhan TFP masih menjadi perdebatan, apakah aliran FDI dipengaruhi oleh TFP atau tidak. Beberapa studi empiris telah dilakukan untuk menguji hal tersebut (Alfaro, Kalemli-Ozcan, dan Sayek, 2009; Borensztein, Gregorio, dan Lee, 1998; Azman-Saini, Baharumshah, dan Law, 2010).

Setidaknya terdapat tiga hal yang dapat menjelaskan hubungan antara aliran FDI dan pertumbuhan. Pertama, kapasitas absorpsi domestik. Kedua, perkembangan sektor keuangan. Ketiga, tingkat kebebasan ekonomi. Dalam hal ini kapasitas absorpsi domestik dijelaskan melalui perbedaan teknologi. Apabila perusahaan domestik semakin tertinggal dari

16 Disusun atas 12 komponen: stabilitas pemerintahan, kondisi sosial-ekonomi, profil investasi, konflik internal, konflik eksternal, korupsi, militer dalam politik, ketegangan agama, hukum dan ketertiban, ketegangan etnis, akuntabilitas demokratis, serta kualitas birokrasi. Lihat International Country Risk Guide Methodology, The Political Risk Services (PRS) Group, 2013. 
perusahaan multinasional, maka semakin banyak manfaat yang diperoleh dari proses mengejar ketertinggalan tersebut. Pada penelitian ini, tingginya pertumbuhan TFP negara-negara ASEAN 5 (kecuali Singapura) terjadi karena semakin sedikit barang modal di negara tersebut, sehingga biaya untuk menyesuaikan penggunaan teknologi semakin rendah.

Hasil temuan pada kasus Singapura sebagai negara tujuan investasi menunjukkan bahwa aliran FDI ke Singapura diinvestasikan bukan untuk kegiatan produksi di industri-industri yang didukung oleh sumber daya alam. Beberapa industri di Singapura yang menerima aliran FDI dalam jumlah besar di antaranya perdagangan dan perniagaan, keuangan, serta perumahan. Dengan demikian, motif aliran FDI dari negara-negara ASEAN 5 menuju Singapura ialah capital intensive, dan bukan human-capital intensive. Akan tetapi, menurut Rajah dan Govindaraju (2013), Malaysia tengah melakukan transformasi ekonomi dari industri padat modal (capitalintensive) ke industri berbasis pengetahuan (knowledge-based industries) untuk menghadapi tantangan pengembangan sumber daya manusia yang relatif lemah. Sementara itu, Singapura juga berupaya untuk terus mendorong FDI masuk ke negaranya, terutama yang dialokasikan ke industri dengan penggunaan teknologi tinggi.

Pada kasus Singapura sebagai negara tujuan investasi, uji empiris menunjukkan, bahwa variabel independen secara simultan mempengaruhi aliran FDI. Sementaravariasi variabelvariabel independen mampu menjelaskan 51,13\% aliran FDI dari Indonesia, Malaysia, Philipina, dan Thailand ke Singapura. Selain itu, estimasi pada kasus ini menetapkan aliran FDI dari Indonesia ke Singapura (IDN_SGP) sebagai benchmark. Hasilnya, variabel dummy tidak ada yang signifikan.

\section{KESIMPULAN}

Penelitian ini menemukan bukti empiris bahwa GDP per kapita yang merepresentasikan variabel neoklasik, serta rata-rata lama sekolah dan kualitas kelembagaan yang mewakili variabel Lucas menjadi faktor pendorong aliran FDI "downhill" dari Singapura sebagai negara asal investasi (source country) ke negara-negara ASEAN 5. Sebaliknya, variabel Lucas yaitu rata-rata lama sekolah, pertumbuhan TFP, dan kualitas kelembagaan serta tingkat pengembalian modal (MPK) sebagai representasi dari variabel neoklasik menjadi faktor penentu aliran FDI "uphill" dari Indonesia, Malaysia, Philipina, dan Thailand ke Singapura sebagai negara penerima (host country). Hal ini menunjukkan, baik variabel Lucas maupun neoklasik menjadi faktor penentu aliran FDI intra-ASEAN 5. Dengan demikian, fenomena Paradoks Lucas di ASEAN 5 terkonfirmasi, akan tetapi tidak menegaskan neoklasik. Karena pada saat bersamaan, variabel neoklasik yang direpresentasikan dengan MPK juga menjadi faktor penentu aliran FDI "uphill".

Kualitas sumber daya manusia dan risiko politik sebagai representasi dari variabel Lucas merupakan faktor penentu aliran FDI intra-ASEAN baik pada kasus "downhill" maupun "uphill". Perbedaan modal manusia di antara negara asal dan negara penerima memegang 
peranan dalam memengaruhi keputusan investor terkait sektor apa saja yang akan dipilih untuk berinvestasi, baik di dalam maupun di luar negeri. Karena hal ini erat pula kaitannya dengan produktivitas tenaga kerja di suatu negara. Sementara itu, risiko politik sebagai salah satu yang menggambarkan kualitas kelembagaan suatu negara juga menjadi pertimbangan investor. Hal ini dikarenakan investor memerlukan jaminan atas stabilitas fiskal dan moneter manakala terjadi gejolak dalam perekonomian di suatu negara.

Pada penelitian ini, besarnya aliran FDI "downhill" dari Singapura ke Indonesia, Malaysia, Philipina, dan Thailand merupakan bagian dari strategi regionalisasi dalam rangka menciptakan iklim investasi yang kompetitif. Hal ini mengindikasikan motif investasi human capital intensive. Sementara itu, aliran FDI "uphill" dari negara ASEAN 5 lainnya ke Singapura mengindikasikan motif investasi yang capital intensive, bukan human capital intensive.

Aliran modal pada penelitian ini hanya menggunakan proksi aliran FDI dengan net basis. Aliran FDI yang digunakan tidak dibedakan berdasarkan komponennya (modal, laba diinvestasikan kembali, atau pinjaman intra-perusahaan). Aliran modal dalam penelitian ini juga tidak memasukkan investasi portofolio. Sebab, modal tak hanya berbentuk fisik (seperti pabrik, peralatan, maupun persediaan) sebagaimana definisi FDI. Penelitian selanjutnya dengan topik serupa dapat membedakan jenis modal, antara FDI dan investasi portofolio maupun dengan memperhitungkan komponen penyusun masing-masing modal. Hal ini bertujuan untuk memperoleh gambaran aliran modal secara keseluruhan, tidak terbatas pada satu jenis investasi. Selain itu, data FDI yang digunakan dalam penelitian ini tidak melihat investasi secara sektoral. Hal tersebut mengakibatkan tidak dapat diketahuinya karakteristik aliran modal. Untuk penelitian yang akan datang dapat mempertimbangkan aliran FDI secara sektoral.

Implikasi kebijakan dari temuan hasil penelitian ini adalah pemerintah negara-negara ASEAN 5 harus meningkatkan kualitas kelembagaan, terutama stabilitas pemerintahan. Namun demikian, faktor lain yang menyebabkan tingginya risiko politik di setiap negara ASEAN 5 juga perlu diperhatikan, seperti konflik eksternal dan internal, korupsi, kualitas birokrasi, serta kondisi sosial-ekonomi. Untuk itu, pemerintah negara-negara ASEAN dapat melakukan policy cooperation and coordination. Karena di era liberalisasi sektor keuangan, negara dituntut untuk mewujudkan iklim investasi yang kondusif. Tak hanya itu, peningkatan kualitas sumber daya manusia juga perlu dilakukan untuk mendorong aliran modal masuk. Hal ini dilakukan agar investasi yang masuk tidak sekedar mengincar melimpahnya tenaga kerja dengan upah rendah (low-cost unskilled labor), maupun dalam rangka menguasai input produksi. Sehingga aliran modal tidak hanya menguntungkan bagi negara asalnya tetapi juga untuk negara penerima.

Pemerintah juga perlu berhati-hati dalam mengeluarkan kebijakan terkait aliran modal internasional. Aliran FDI yang besar akan diikuti dengan besarnya repatriasi. Hal ini berpotensi mengganggu stabilitas sistem keuangan apabila tidak dikelola dengan hati-hati. Oleh karena itu perlu adanya kebijakan terkait dengan repatriasi dalam valuta asing. 
Paper ini secara eksplisit tidak mengkaji kebijakan moneter. Namun demikian, hal tersebut tidak berarti tidak ada relevansinya dengan kebijakan bank sentral. Aliran FDI yang berkaitan erat dengan lalu lintas devisa yang merupakan salah satu aspek penting dalam stabilitas makroekonomi. Oleh karena itu, kebijakan makroprudensial yang saat ini menjadi domain utama bagi kebijakan Bank Indonesia harus memperhatikan karakteristik FDI beserta implikasinya. 


\section{DAFTAR PUSTAKA}

Alfaro, Laura, S. Kalemli-Ozcan, dan V. Volosovych. (2007). Capital Flows in a Globalized World: The Role of Policies and Institutions.

Alfaro, Laura, S. Kalemli-Ozcan, dan V. Volosovych. (2008). Why Doesn't Capital Flow from Rich to Poor Countries? An Empirical Investigation, The Review of Economics and Statistics, Vol. 90 (2), h. 347-368.

Alfaro, Laura, S. Kalemli-Ozcan, dan S. Sayek. (2009). FDI, Productivity and Financial Development, The World Economy, h. 111-135.

Appleyard, Dennis R., A. J. Field, dan S. L. Cobb. (2010). International Economics (7th Edition). New York: McGraw-Hill.

ASEAN Secretariat. (2013). ASEAN Investment Report 2012: The Changing FDI Landscape. Jakarta: The ASEAN Secretariat.

ASEAN Secretariat. (2014). ASEAN FDI Database. Jakarta: The ASEAN Secretariat.

Azman-Saini, W. N. W., A. Z. Baharumshah, dan S. H. Law. (2010). Foreign Direct Invetment, Economic Freedom and Economic Growth: International Evidence, Economic Modelling, Vol. 27, h. 1079-1089.

Baltagi, Badi H. (2008). Econometrics (4th Edition). New York: Springer-Verlag Berlin Heidelberg.

Blomqvist, Hans C. (2002). Extending The Second Wing: The Outward Direct Investment of Singapore, Department of Economics Working Papers 3, University of Vaasa.

Borensztein, E., J. De Gregorio, J-W. Lee. (1998). How does Foreign Direct Investment Affect Economic Growth?, Journal of International Economics, Vol. 45, h. 115-135.

Djaafara, Rizal A., dkk (Eds). (2012). Masyarakat Ekonomi ASEAN 2015: Proses Harmonisasi di Tengah Persaingan. Jakarta: Bank Indonesia.

Ellingsen, Gaute, W. Likumahuwa, dan P. Nunnenkamp. (2006). Outward FDI by Singapore: A Different Animal?, Transnational Corporations, Vol. 15, No. 2, h. 1-40.

Herrmann, Sabine, dan J. Kleinert. (2014). Lucas Paradox and Allocation Puzzle - Is the Euro Area Different?,Discussion Paper No. 06/2014. Frankfurt am Main: Deutsche Bundesbank.

Hsu, Locknie. (2013). Singapore: Inward FDI and Its Policy Context, 2012, Inward and Outward FDI Country Profiles (2nd Edition), h. 1022-1043. New York: Vale Columbia Center on Sustainable International Investment. 
Kementerian Luar Negeri RI. (2012). ASEAN Selayang Pandang (Edisi 20). Jakarta: Direktorat Jenderal Kerja Sama ASEAN Kementerian Luar Negeri RI.

Lucas, Robert E. (1990). Why Doesn't Capital Flow from Rich to Poor Countries? The American Economic Review, Vol. 80 (2), h. 92-96.

Mankiw, N. Gregory. (2013). Macroeconomics (8th Edition). New York: Worth Publishers.

Okada, Keisuke. (2013). The Interaction Effects of Financial Openness and Institutions on International Capital Flows, Journal of Macroeconomics, Vol. 35, h. 131-143.

Pogoda, Barbara. (2012). The Lucas Paradox, Master's thesis, UniversitatBielefeld.

Rajah, Raisah dan C. Govindaraju. (2013). Malaysia: Inward FDI and Its Policy Context, 2011, Inward and Outward FDI Country Profiles (2nd Edition), h. 894-907. New York: Vale Columbia Center on Sustainable International Investment.

Salvatore, Dominick. (2013). International Economics (11th Edition). New York: John Wiley \& Sons.

Tambunan, Tulus H. (2013). Indonesia: Inward FDI and Its Policy Context, 2011, Inward and Outward FDI Country Profiles (2nd Edition), h. 878-893. New York: Vale Columbia Center on Sustainable International Investment.

World Bank. 2015. World Development Indicators. Washington DC: The World Bank.

Yeung, Henry Wai-chung. (1999). Singapore's Global Reach: An Executive Report. Singapore: National University of Singapore. 